\title{
アンケート 外国人研でいら日大日本のR\&D
}

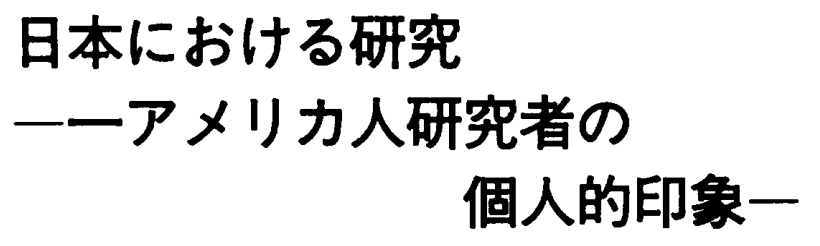

Scott Douglas Gray
1957 年 12 月生まれ. 出身国：アメリカ 出身学校：アメリカ・パデュー大学機械工学科 在日期間： 1 年 (1989 年 9 月から)

略歴：GE 社において機械設計一般, CAE System の検討プロジェクトの参加, 新分野の開発，などプロジェクトのコンサ ルタントエンジニア

日本での勤務先：日産自動車車研究所 （テ 237 横須賀市夏岛町 1)

\section{1.はじめに}

私は日産自動車での研究生活の最初の 5 简月目を終 えたところです。アメリカでの仕事や学習を通じて国 際的経験の重要性を認識するに至り，そして日本へ来 ようと決心しました。なぜ日本なのかと言うと，私は 日本人の仕事や品質への思い入れに尊敬の念を持った からです. 㷌国後はサンディア国立研究所の研究員と なる予定です。

\section{2. 日本の研究について}

製品の開発に関する側面に限って言うと，日本の研 究はアメリカのそれよりも奻率が良いように見えま す.アメリカでの研究の目指すところは, “ブレーク スルー”であって, この目的が達成されない時は, そ の研究は単に学会や研究者だけに益するものとなるこ とがしばしばであります。それに対して，日本の研究 の目的は“改良”に焦点があっていて，小さなイノべ

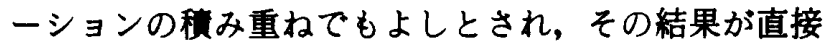
に製品に反映されていることが多いと思います。この ような, 応用に当たっての高い効率は次のような理由 によるものと私は受け取っています。

(1) 日本の研究は応用フェースにそのほとんどが集 中している，そして，先行開発の機能と近い位置づけ であることが多い.

(2) 研究は実験をべースとして始められていて（実 際の製品が試供品として使われるケースも多い)，し たがって得られる結果も幣品への応用が容易.

(3) 研究成果の応用先が明確になっていて, 結果を 出すタイミングもよく計画され，かつ，実行されてい る.

（4）研究者たちは結果を得ることに集中していて， 研究過程での新しい数学的解析手法の試みなど, 寄り 道の部分に反れて行かない.

（5）日本の管理者たちは，彼らを取巻くいろいろな 環境についての洞察の必要性を理解した上で，それを 直接研究テーマの発掘設定に生かしている.

\section{3. 研究施設について}

ハードウェアは良く装備され，また，不足している 物も速やかに補てんされて行っているように思いま す。ソフトウェアツールは利用可能な状態ではありま すが, 能力をフルに発揮していないようです。その理 由は，多くのソフトウェアが英語で書かれているため のランゲージバリアーであると信じます。

\section{4. 数高について}

アメリカの研究機関に比べて, 日本の企業内研究所 では博士などの学位所持者の割合が少ないように感じ ます。しかしその一方，日本の研究者は製品に関する 高度な知識を広い技術分野にわたって有していると思 います。

\section{5. 結}

私は日本の研究システムに大変強い印象を受けまし た.そして，イノベーションを製品につなげていく面 で極めて効率が良いことに気が付きました。ただし， もし日本の研究の弱点をあえて指摘せよと求められれ ば，私は次の二点をあげたいと思います．第一に，大 学の学部段階における理論解析力開発のレベルは向上 の余地が大きいのではないでしうか。私のような外 国人からみると日本の教科書はまるで工学ハンドブッ クのよう（総花的な浅い著述）に見えます．第二に， 日本の研究者が研究の結果を重んじるあまり, 解析手 法やソフトウェアツール（例えば有限要素法プログラ ム）を“フララックボックス”として使ってしまう環境 が出来上がっていないてしょうか.もしし開発のサイク ルをもっともっと短くしようと思うなら，実験に頼る 比率を少なくし, 解析手法の正しい適用を重んじなけ ればならないはずです。のためには, 解析手法やソ フトゥェアの深い理解が不可欠だと思います。

もちろん，今うまくいっている開発システム内にあ って，その弱点を見つけたり，批判を加えたりするこ とは常に難しいことではありますが.

〔日産自動車(株) 石浜 正男 訳] （原稿受付 1990 年 2 月 7 日） 